\title{
PENGARUH SENAM KAKI TERHADAP PENURUNAN RESIKO NEUROPATI \\ PERIFER DENGAN SKOR DIABETIC NEUROPATHY EXAMINATION PADA \\ PASIEN DIABETES MELITUS TIPE 2 DI PUSKESMAS SIBELA KOTA SURAKARTA
}

\author{
Desy Indah Ratnawati, Insiyah \\ Kementerian Kesehatan Politeknik Kesehatan Surakarta Jurusan Keperawatan
}

\begin{abstract}
Foot Gymnastics, Diabetic Neuropathy Examination Score. Peripheral neuropathy is one of chronic complications frequently found in diabetes mellitus case. The risks of the diabetic patient with peripheral neuropathy face included repeated infection, refractory ulcer and finger and foot amputation. This condition requires an easy and cheaper primary treatment, foot gymnastic. This research aimed to find out the effect of foot gymnastic on the decreased peripheral neuropathy with diabetic neuropathy examination score in patients with type 2 diabetes mellitus in Puskesmas (Public Health Center) Sibela in Surakarta City. The Research Methods could be used design using quasy experiment design with one group method pre test-post test. The samples are 30 participant of foot gymnastics at Puskesmas Sibela in February until April 2015. This research use paired t test in order to know risk decrease of peripheral neuropathy by diabetic neuropathy examination score. The results could from 30 respondents is obtained a mean diabetic examination neuropathy score before foot gymnastics was 7,67 with a standard deviation of 2,63 and after foot gymnastics was 5,37 with a standard deviation of 2,632. From the paired t test analysis was obtained $p$ $=0,001(p<0,05)$. Conclusion existence of influence foot gymnastic againts a decreased risk of peripheral neuropathy based on diabetic neuropathy examination scores. Suggestion for the next research measurement diabetic neuropathy examination scores for 3 to 6 months to obtain optimal result.
\end{abstract}

Keywords: Foot Gymnastics, Diabetic Neuropathy Examination Score

Abstrak : Senam Kaki, Score Diabetic Neuropathy Examination. Neuropati perifer merupakan salah satu komplikasi kronis yang sering ditemukan pada kasus diabetes melitus. Risiko yang dihadapi pasien diabetes melitus dengan neuropati perifer adalah infeksi berulang, ulkus yang tidak sembuh sembuh dan amputasi jari dan kaki. Kondisi inilah yang menyebabkan perlunya perawatan primer yang mudah dan murah yaitu senam kaki. Penelitian ini bertujuan mengetahui pengaruh senam kaki terhadap penurunan resiko neuropati perifer dengan skor diabetic neuropathy examination pada pasien diabetes melitus tipe 2 di Puskesmas Sibela Kota Surakarta. Rancangan penelitian ini menggunakan desain quasy eksperimen dengan metode one group pre tespost test, sampel yang digunakan sebanyak 30 responden yang dilakukan senam kaki di Puskesmas Sibela pada bulan Februari sampai dengan bulan April 2015. Penelitian ini menggunakan uji paired t test yang digunakan untuk mengetahui penurunan resiko neuropati perifer berdasarkan skor diabetic neutopathy examination. Dari 30 responden didapatkan hasil rerata skor DNE sebelum senam kaki adalah 7,67 dengan standar 
deviasi 2,496, sesudah senam kaki 5,37 dengan standar deviasi 2,632. Dari analisis uji paired t test didapatkan $\mathrm{p}=0,001(\mathrm{p}<0,05)$. Dari penelitian tersebut disimpulkan adanya pengaruh senam kaki terhadap penurunan resiko neuropati perifer berdasarkan skor diabetic neuropathy examination. Untuk penelitian selanjutnya pengukuran skor diabetic neuropathy examination selama 3 sampai 6 bulan untuk mendapatkan hasil yang optimal.

\section{Kata Kunci : Senam Kaki, Score Diabetic Neuropathy Examination}

\section{PENDAHULUAN}

Diabetes Melitus merupakan penyakit sillent killer yang ditandai dengan peningkatan kadar glukosa darah dan kegagalan sekresi insulin atau penggunaan insulin dalam metabolisme yang tidak adekuat. Kegagalan sekresi atau ketidak adekuatan penggunaan insulin dalam metabolisme tersebut menimbulkan gejala hiperglikemia, sehingga untuk mempertahankan glukosa darah yang stabil membutuhkan terapi insulin atau obat pemacu sekresi insulin (Soegondo, 2013).

Secara klinis terdapat dua tipe diabetes, yaitu DM tipe 1 yang disebabkan kurangnya insulin secara absolute akibat autoimun dan DM tipe 2 yang merupakan kasus terbanyak (90-95\% dari seluruh kasus diabetes) yang umumnya mempunyai latar belakang kelainan diawali dengan resistensi insulin (American council on exercise, 2001; Smeltzer \& Bare, 2008).

Diabetes melitus tipe 2 berlangsung lambat (selama bertahun tahun) dan progresif, sehingga berjalan tanpa terdeteksi karena gejala yang dialami pasien sering bersifat ringan seperti kelelahan, iritabilitas, poliuria, polidipsi, dan luka yang lama sembuh (Smeltzer \& Bare, 2008).

Prevalensi diabetes semakin meningkat. Organisasi Kesehatan Dunia (WHO) menyatakan pada tahun 2010 sedikitnya 279,3 juta orang mengalami diabetes. Insiden akan meningkat dua kali lipat pada tahun 2030 menjadi 366 juta jiwa. Di Indonesia, pada tahun 2000-an, penduduk yang berusia diatas 20 tahun adalah 125 juta jiwa. Jika prevalensi kejadian DM 4.6 \%, maka jumlah pasien DM 5.6 juta jiwa. Berdasarkan pola pertambahan penduduk seperti ini, diperkirakan awal tahun 2020 jumlah penduduk Indonesia yang berusia di atas 20 tahun sekitar 178 juta jiwa dan diasumsikan akan terjadi kenaikan prevalensi kejadian DM sekitar 8,2 juta jiwa (Diabetes Atlas 2000 dalam Sudoyo, 2009).

Seiring dengan peningkatan jumlah penderita DM, maka komplikasi yang terjadi juga semakin meningkat, diantaranya adalah retinopathy, penyakit jantung, nephropati, luka kaki diabetes, dan neuropathy. Neuropati adalah salah satu komplikasi kronik diabetes yang paling ditakuti. Manifestasi klinis neuropathy perifer dapat berupa gangguan fungsi sensorik. Biasanya terdapat gejala kehilangan fungsi yang disertai dengan kekebasan, tremor, dan abnormalitas cara berjalan dan gangguan fungsi motorik yang ditandai dengan kehilangan fungsi. Gejalanya seperti kelemahan, kelelahan, terasa berat, kelainan gaya berjalan, kram, tremor, kesemutan dan bengkak. Neuropathy perifer merupakan masalah yang kompleks dan menjadi alasan 
penderita diabetes melitus menjalani perawatan. Jika masalah neuropathy perifer tidak segera di atasi maka akan menyebabkan kelumpuhan dan kaki diabetic, sehingga pasien membutuhkan perawatan di rumah sakit (Soegondo, 2013).

Neuropathy perifer dapat dicegah hanya pada bentuk - bentuk dimana penyakit yang mendasarinya dapat dicegah. Hal hal yang dapat dilakukan seseorang untuk pencegahan diantaranya adalah vaksinasi terhadap penyakit penyakit yang dapat menyebabkan neuropathy perifer seperti polio dan difteri (ADA, 2011). Selain menggunakan vaksinasi, neuropathy perifer dapat dicegah dengan edukasi, perencanaan makan (diet), pengobatan medis, pemantauan, dan latihan jasmani (Syahbudin, 2002, dalam Suyono, 2005). Tindakan pencegahan tersebut yang paling efektif dan berpengaruh terhadap neuropathy perifer adalah melakukan latihan jasmani salah satunya yaitu senam kaki. Senam kaki dapat membantu pasien untuk memperbaiki masalah sirkulasi aliran darah kaki. Biasanya penderita diabetes yang sudah lama cenderung memiliki masalah sirkulasi yang lebih serius karena kerusakan aliran darah yang melalui arteri lebih kecil, hal ini menambah kerentanan terhadap luka luka di kaki yang memerlukan waktu yang lama untuk di sembuhkan dan bahaya terkena infeksi. Bila dilakukan deteksi dini dan pengobatan yang adekuat akan dapat mengurangi kejadian infeksi akibat neuropathy perifer. Ironisnya evaluasi dini dan penanganan yang adekuat di rumah sakit tidak optimal (Soegondo, 2013).

Dari laporan studi pendahuluan yang peneliti lakukan di Puskesmas Sibela
Mojosongo didapatkan jumlah pasien 110 orang yang menderita diabetes melitus tipe 2 yang belum pernah dilakukan senam kaki. Jadi untuk mencegah terjadinya neuropathy perifer harus dilakukan senam kaki untuk menurunkan resiko tersebut.

Berdasarkan fenomena tersebut peneliti tertarik untuk melakukan penelitian dengan judul "Pengaruh Senam Kaki Terhadap Penurunan Resiko Terjadinya Neuropathy Perifer Dengan Skor Diabetic Neuropathy Examination".

\section{METODE PENELITIAN}

Desain penelitian ini adalah Deskriptif kuantitatif dengan pengukuran skor DNE sebelum senam kaki dan sesudah senam kaki pada responden yang mengalami diabetes melitus tipe 2 . Rancangan penelitian dapat dilihat dalam skema sebagai berikut :

Skema 1.

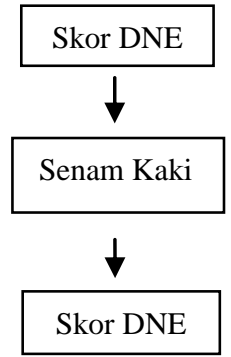

\section{HASIL PENELITIAN}

Analisis statistik univariat bertujuan untuk mendiskripsikan karakteristik masing - masing variabel yang diteliti. Hasil analisis statistik univariat sebagai berikut : 
1. Karakteristik Responden Jenis Kelamin dan Umur

\begin{tabular}{cll}
\multicolumn{2}{c}{ Tabel 1 } \\
\multicolumn{3}{c}{ Karakteristik Subyek Penelitian } \\
\hline No & Karakteristik & Kelompok \\
& & Perlakuan \\
\hline 1 & Jumlah Subyek & 30 subyek \\
2 & Umur & \\
& a. Mean & 60,77 \\
& b.SD & 8,63 \\
3 & Jenis Kelamin & \\
& a.Laki laki & 12 orang ( 40\%) \\
& b.Perempuan & 18 orang $(60 \%)$ \\
\hline
\end{tabular}

Dari tabel 1 diatas karakteristik subyek penelitian diketahui berjumlah 20 orang. Umur rata rata 60,77 dengan SD 8,63 . Subyek penelitian terdiri dari 18 orang perempuan $(60 \%)$ dan 12 orang laki laki $(40 \%)$.

2. Distribusi Rata - rata Skor DNE Sebelum dan Sesudah Senam Kaki

Tabel 2

Distribusi Rata rata Skor DNE

\begin{tabular}{lccc}
\hline Variabel & $\mathrm{N}$ & Mean & P value \\
\hline Skor & 30 & 7,67 & \\
DNE & & & \\
Sebelum & & & \\
Senam & & & \\
Kaki & & & 0,00 \\
Skor & 30 & 5,37 & \\
DNE & & & \\
Sesudah & & & \\
Senam & & & \\
Kaki & & & \\
\hline
\end{tabular}

Berdasarkan tabel 2, dipaparkan Nilai rearata sebelum perlakuan 7,67 dan sesudah perlakuan 5,37. Dari hasil tersebut terdapat perbedaan nilai yang menunjukkan makna yang signifikan yang berarti penurunan resiko neuropati.

Penurunan resiko neuropati diukur dengan Skor Diabetic Neuropathy Examination pada kelompok perlakuan sebelum dan sesudah senam kaki. Untuk mengetahui ada tidaknya perbedaan Skor DNE saat awal (pre) dan saat akhir penelitian (post) pada kelompok, dilakukan analisis inferensial dengan menggunakan uji paired t test.

Sebelum data dianalisis dengan uji Paired t test, terlebih dahulu dilakukan uji normalitas untuk memastikan untuk memastikan bahwa data berdistribusi normal. Pada penelitian ini, hasil uji normalitas (uji Shapiro-Wilk) terhadap data nilai Skor DNE kelompok perlakuan senam kaki.

Hasil uji beda Skor DNE sebelum $\&$ sesudah menggunakan senam kaki pada kelompok perlakuan 3 bulan menggunakan uji Paired t test, didapatkan hasil $\mathrm{p}=0,00(\mathrm{p}<0,05)$, ini berarti pemakaian uji $t$ tes ada pengaruh yang signifikan

Untuk mengetahui yang paling berpengaruh diantara skor sebelum dan sesudah dari selisih mean derajat pre dan post. Selisih mean yang didapatkan adalah 2,30 dengan standar deviasi 4,56.Dengan demikian dapat disimpulkan bahwa ada pengaruh senam kaki terhadap penurunan resiko neuropati perifer pada pasien diabetes melitus tipe 2 .

\section{PEMBAHASAN}

Pada analisis univariat diketahui bahwa subyek penelitian ini berumur antara 45 hingga 81 tahun dengan umur rata rata 60,77 tahun dan paling sering terjadi adalah perempuan.

Menurut Helmanu K \& Ulfa Nurrahmani (2014), pada penderita diabetes, gula darah yang meningkat dalam jangka waktu lama akan menyebabkan kelainan saraf yang disebut dengan neuropati dan kelainan pembuluh darah. Keadaan ini mengakibatkan rasa terhadap rangsang sakit menurun, 
perubahan kekuatan motorik sehingga timbul perubahan tekanan pada telapak kaki. Keringat juga berkurang sehingga kulit menjadi kering dan dapat memudahkan menimbulkan luka. Kelainan pembuluh darah (penyempitan) menyebabkan adanya bagian kaki yang suplai darahnya berkurang (iskemia) sehingga kelainan - kelainan tersebut lebih sukar dikelola dan susah sembuh.

Pada kondisi neuropati pembuluh darah besar tungkai seringkali terjadi komplikasi. Kelainan ini disebabkan oleh penebalan dinding pembuluh darah besar atau yang lazim disebut aterosklerosis. Dengan penebalan tersebut, aliran darah tungkai dan kaki menjadi tidak lancar dan berkurang sehingga menimbulkan beberapa keluhan seperti kaki terasa dingin, kram otot tungkai, dan kulit kering. Keadaan ini juga sering didapati bersamaan dengan komplikasi neuropati. Neuropati berperan pada komplikasi ini terutama adalah neuropati pada kaki yang menyebabkan mati rasa (baal). Mati rasa menyebabkan penderitanya tidak akan merasakan apa apa walaupun kakinya terluka parah. Jika tidak cepat diatasi, apalagi kemasukan kuman (infeksi), maka kaki yang luka tersebut bisa menjadi borok parah dan bisa terancam diamputasi. Oleh karena itu, penderita diabetes sangat dianjurkan melakukan senam kaki dengan teratur.

\section{KESIMPULAN DAN SARAN}

Dalam penelitian ini ditemukan bahwa ada pengaruh senam kaki $(\mathrm{p}=0,000<0,05)$, artinya setelah dilakukan senam kaki selama 3 bulan ternyata terjadi penurunan Skor DNE pada pasien diabetes melitus tipe 2 di Puskesmas Sibela.

\section{DAFTAR RUJUKAN}

American Diabetes Association. (2011). Diabetes Ready Reference For Nurse Practitioners. Edisi : 3. Wolfs- Dorf.

Helmanu, K \& Ulfa, N. (2014). Stop Diabetes, Hipertensi, Kolesterol Tinggi, Jantung Koroner. Edisi : 1. ISBN : 97860214307.

Logerfo, LJ. (2002). Diabetic Foot And Vascular Complication. Edisi : 5. USA: Elseiver Saunders.

Misnadiarly. (2006). Diabetes Mellitus; Gangren, Ulcer, Infeksi, Mengenal Gejala, Mengenanggulangi Dan Mencegah Komplikasi. Edisi : 1. Jakarta : Pustaka Populer Obor.

Suyono, S. (2005). Diabetes Mellitus ; Mekanisme Dasar Dan Pengelolaan Yang Rasional. Edisi : 1. Jakarta : Balai Penerbit FKUI.

Waspadi, S. (2006). Kaki Diabetes. Edisi : IV. Jakarta : EGC.

Widhiarso, W. (2012). Uji Normaltas. Diunduh Dalam: http//widhiarso.staff.ugm.ac.id Pada Tanggal 10 Januari 2015 Jam 10.00 WIB. 